\title{
Small cell carcinoma of the oesophagus: report of three cases and review of published cases
}

\author{
DIANA M ECCLES, SIMON G ALLAN, CHRISTOPHER T M SANG, \\ MICHAEL A CORNBLEET

\begin{abstract}
From the Imperial Cancer Research Fund Medical Oncology Unit, University Department of Clinical Oncology, Western General Hospital, and the Department of Cardiothoracic Surgery, City Hospital, Edinburgh
\end{abstract}

\begin{abstract}
Small cell carcinoma of the oesophagus is a rare tumour with a poor prognosis. This report presents evidence favouring chemotherapy as the primary treatment.
\end{abstract}

Since it was first described in 1952 by McKeown, ${ }^{1}$ primary small cell carcinoma of the oesophagus has been reported with increasing frequency, and more than 80 cases have now been published. The natural history and median survival are reported to be very similar to that of small cell lung carcinoma. $^{2}$ We present three cases and evidence from published reports indicating that this is a chemosensitive and radiosensitive disease.

\section{Case reports}

\section{CASE 1}

A 70 year old woman, a non-smoker, presented with increasing dysphagia of nine months' duration. Endoscopy showed a polypoid, circumferential tumour at $25 \mathrm{~cm}$, extending distally for $7 \mathrm{~cm}$. A biopsy specimen showed undifferentiated small cell carcinoma. Bronchoscopy and ultrasound and isotope scanning of the liver showed nothing abnormal. She was treated with radical radiotherapy to the oesophagus with a complete symptomatic response. Two months later she had developed liver metastases and was bed bound with nausea and lethargy. She was treated with four cycles of chemotherapy (table) and improved symptomatically. She died two months later (nine months after diagnosis) with widespread metastatic disease.

\section{CASE 2}

A 38 year old woman, a smoker, presented with a three year history of pain on swallowing and a short history of dysphagia with solids. Biopsy specimens of an oesophageal tumour, extending from 23 to $37 \mathrm{~cm}$, showed undifferentiated small cell carcinoma. Bronchoscopy showed nothing abnormal. She underwent subtotal oesophagectomy; at operation the tumour was found to be penetrating the oesophageal wall, and two of 11 adjacent lymph nodes were replaced by metastatic tumour. No residual disease in the mediastinum, lung parenchyma, or liver was visible on a

Address for reprint requests: Dr D M Eccles, ICRF Medical Oncology Unit, Western General Hospital, Edinburgh EH4 2XU.

Accepted 12 April 1989 postoperative computed tomogram. She received four cycles of chemotherapy (table), and is disease free as judged by endoscopy 24 months from diagnosis.

\section{CASE 3}

A 67 year old man, a smoker, presented complaining of epigastric discomfort, tiredness, and lethargy. Oesophagoscopy showed a $5 \mathrm{~cm}$ tumour in the distal posterior oesophageal wall, which proved to be an undifferentiated small cell carcinoma. Bronchoscopy showed nothing abnormal. An enlarged lymph node in the right supraclavicular fossa was infiltrated by metastatic small cell carcinoma, but there were no liver or lung metastases. He had four cycles of combination chemotherapy (table) and achieved complete remission as judged by endoscopy. He died suddenly 25 months after diagnosis of a myocardial infarction with no evidence of primary or metastatic tumour.

\section{Discussion}

Small cell carcinoma of the oesophagus is a rare tumour that appears to be increasing in incidence. It accounts for $0.05 \%-7.6 \%$ of all oesophageal tumours, and seems to be more prevalent in Japan. ${ }^{3}$ Like small cell lung carcinoma, the disease is characterised by early dissemination and a median survival of under five months. ${ }^{2}$ Aetiology and histogenesis are uncertain, but there is an association between small cell carcinomas, including extrapulmonary ones, ${ }^{45}$ and smoking. $^{45}$

Doherty et $a l^{6}$ reported six British patients with primary oat cell carcinoma of the oesophagus treated initially with local radiotherapy. The median survival was three months and all patients died of metastatic disease. In a Japanese series of six cases ${ }^{3}$ primary treatment was by surgical resection only. Four patients died within nine months of

Chemotherapeutic regimen used in the treatment of small cell oesophageal carcinoma

Methotrexate $200 \mathrm{mg} / \mathrm{m}^{2} 24$ hour infusion

Folinic acid rescue starting 26 hours after start of methotrexate infusion, $15 \mathrm{mg} 6$ hourly: four intravenous doses then four oral doses

Cyclophosphamide $1 \mathrm{~g} / \mathrm{m}^{2}$ intravenous infusion day 1

Etoposide (VP16) $120 \mathrm{mg} / \mathrm{m}^{2}$ intravenous infusion days 1,2 , and 3

Standard antiemetic regimen

Treatment repeated every 21 days if blood count satisfactory 
widespread disease, but a 71 year old man was alive and disease free 24 months later and a 56 year old man did not have any recurrence until 14 months after operation.

Two single case reports ${ }^{78}$ document the use of combination chemotherapy with partial remission and survival of nine months in both cases, and Levenson et al $^{9}$ reported a complete remission after combination chemotherapy. This last patient died in an accident 11 months after diagnosis and no tumour was found at necropsy. We report two additional patients, who were disease free 24 and 25 months after combination chemotherapy. Our other patient had primary local treatment with radiotherapy, developed metastatic disease two months after completing treatment, and survived only nine months.

Local control of small cell carcinoma of the oesophagus may be achieved by radiotherapy or surgery, but this review of the natural history indicates that metastatic disease is likely to be present at the outset. Systemic chemotherapy should therefore be considered the treatment of choice, either alone or in combination with definitive local treatment. Though the optimum drug regimen has not been established, our experience would suggest that those drugs that are most active in combination against small cell lung cancer are appropriate.

We are grateful to Mr J M T Griffiths (case 3), consultant surgeon, Eastern General Hospital, Edinburgh, and $\mathrm{Mr}$ E W J Cameron (case 1), consultant thoracic surgeon, City
Hospital, Edinburgh, for permission to report patients originally in their care.

\section{References}

1 McKeown F. Oat-cell carcinoma of the oesophagus. $J$ Pathol Bacteriol 1952;65:889-92.

2 Sabanathan S, Graham GP, Salama FD. Primary oat cell carcinoma of the oesophagus. Thorax 1986;41:318-21.

3 Tateishi R, Taniguchi T, Horai T, et al. Argyrophil cell carcinoma (apudoma) of the esophagus: a histopathologic entity. Virchows Arch A Pathol Anat Histol 1976;371:283-94.

4 Briggs JC, Ibrahim NBN. Oat cell carcinoma of the oesophagus: a clinico-pathological study of 23 cases. Histopathology 1983;7:261-77.

5 Remick SC, Hafez GR, Carbone PP. Extrapulmonary small-cell carcinoma. A review of the literature with emphasis on therapy and outcome. Medicine (Baltimore) 1987;66:457-71.

6 Doherty MA, McIntyre M, Arnott SJ. Oat cell carcinoma of esophagus: A report of six British patients with a review of the literature. Int J Radiat Oncol Biol Phys 1984;10:147-52.

7 Kelsen DP, Weston E, Kurtz R, Cvitkovic E, Lieberman P, Golbey RB. Small-cell carcinoma of the esophagus: Treatment by chemotherapy alone. Cancer 1980;45:1558-61.

8 Tanabe G, Kajisa T, Shimazu H, Yoshida A. Effective chemotherapy for small cell carcinoma of the esophagus. Cancer 1987;60:2613-6.

9 Levenson RM, Ihde DC, Matthews MJ, et al. Small cell carcinoma presenting as an extrapulmonary neoplasm: sites of origin and response to chemotherapy. J Natl Cancer Inst 1981;67:607-12. 